\title{
EVALUASI KEBIJAKAN PENCALONAN ANGGOTA DPRD DALAM PENYELENGARAAN PEMILU TAHUN 2014
}

\section{POLICY EVALUATION OF DISTRICT PARLIAMENT MEMBER NOMINATION IN GENERAL ELECTION 2014}

\author{
Tatang Sudrajat \\ Fakultas IImu Komunikasi dan Administrasi \\ Universitas Sangga Buana (USB) YPKP Bandung \\ Jl.P.H. Hasan Mustafa no.68 Bandung \\ Telp. 081743554 \\ Email : id.tatangsudrajat@gmail.com
}

Naskah diterima: 6 Oktober 2016, revisi: 7 Desember 2016

\begin{abstract}
The nomination policy of local parliament members in general election is regulated in various policies by the Central Parliament, the President and the Election Commission. In order to improve the election quality, policy evaluation is required. This study uses legal research/normative methods and library/documentary study of the policies content. It is found out that there are some different aspects in managing the nomination of local parliament members in Law No. 8 of 2012 and some Election Commission/KPU's regulations. Substantively, there are several provisions that are ambiguous, multi-interpretative, contradictious, and are not implementable. This problem causes local election commissions cannot optimally perform theirs tasks. Therefore, it is recommended to have policy revision in several aspects, such as education qualification, physical and spiritual health, authorized health agency, political liaison officers, resignation certificate or decree from certain positions at public agencies (such as civil servant, military, police, etc.) and other institutions to avoid conflict of interest, nomination forms, and several errors/ inconsistencies terms.
\end{abstract}

Keywords: policy evaluation, local parliament nomination, general election.

\begin{abstract}
Abstrak
Pencalonan anggota DPRD dalam pemilu diatur dalam berbagai kebijakan yang ditetapkan DPR, Presiden dan KPU. Untuk penyelenggaraan yang makin berkualitas di masa yang akan datang, diperlukan evaluasi kebijakan. Dengan metode penelitian hukum/hukum normatif dan teknik studi kepustakaan/dokumenter terhadap isi/substansi kebijakan diketahui adanya berbagai aspek pengaturan pencalonan anggota DPRD, yang termuat dalam UU Nomor 8 Tahun 2012 dan beberapa produk kebijakan KPU yang pada dasarnya merupakan kebijakan publik. Secara substantif terdapat beberapa ketentuan
\end{abstract}


yang bersifat tidak jelas, multiinterpretatif, kontradiktif dan tidak implementatif. Kondisi ini mengakibatkan para penyelenggara pemilu di daerah tidak dapat melaksanakan tugas pelayanan pencalonan secara lebih optimal. Untuk itu, direkomendasikan perlu adanya penyempurnaan terhadap substansi beberapa aspek pencalonan anggota DPRD, yang meliputi ijazah/STTB, surat keterangan sehat jasmani dan rohani, institusi pemberi surat keterangan sehat, petugas penghubung parpol dengan penyelenggara pemilu, surat keterangan atau surat keputusan pemberhentian dalam kedudukan/jabatan tertentu (PNS, TNI, Polri, dan sebagainya), surat pernyataan pengunduran diri, badan lain yang anggarannya dari keuangan negara, pekerjaan lain yang tidak menimbulkan konflik kepentingan, beberapa contoh formulir/model pencalonan dan beberapa kesalahan/ inkonsistensi peristilahan.

Kata kunci: evaluasi kebijakan, pencalonan anggota DPRD, pemilihan umum.

\section{A. PENDAHULUAN}

Pada tahun 2019 akan ada agenda kenegaraan penting yaitu pemilihan umum (pemilu) untuk memilih anggota DPR, DPD dan DPRD serta Presiden dan Wakil Presiden yang pemungutan suaranya dilaksanakan pada hari yang sama. Pemerintah saat ini sedang menyiapkan draf undang-undang yang akan disampaikan ke DPR untuk menggantikan beberapa undang-undang kepemiluan yang saat ini berlaku (Kompas, 30/8/2016). Tentu saja hal ini merupakan episode baru yang akan menorehkan sejarah perjalanan kepemiluan dan demokrasi di Indonesia. Dalam konteks ini sangat disadari pentingnya pemilu yang makin berkualitas sehingga akan menjadi perhatian saksama dari para pemangku kepentingan (stakeholders) pemilu, khususnya pemerintah, DPR, Komisi Pemilihan Umum (KPU) dan para pemerhati pemilu. Hal ini terlebih-lebih karena pemilu yang akan datang merupakan pemilu bercorak baru sehingga memerlukan kesungguhan dalam mempersiapkannya, khususnya dalam bentuk undang-undang kepemiluan.

Selepas kemunduran Presiden Soeharto tahun 1998, tampak sangat kuat semangat untuk mereformasi tatanan politik dan ketatanegaraan sehingga terjadi rangkaian pengubahan bahkan penggantian undang-undang, khususnya terkait dengan pencalonan anggota badan legislatif. Hal ini selaras dengan dinamika perkembangan masyarakat saat itu yang sangat menghendaki lahirnya sistem politik yang makin demokratis, selain juga sebagai entry point lahirnya lembaga perwakilan rakyat yang kredibel dan akseptabel. Publik banyak berharap agar penyelenggaraan pemilu anggota DPR, DPD dan DPRD (yang lazim di masyarakat disebut pemilu legislatif dengan akronim pileg) ini akan makin berkualitas. Dalam konteks ini, yang termasuk publik diantaranya adalah pengurus parpol, bakal calon anggota badan legislatif serta kalangan civil society pemerhati pemilu.

Pengalaman empat kali penyelenggaraan pileg pascarezim Orde Baru menunjukkan adanya berbagai hal yang terus mendapat perbaikan, termasuk regulasinya. Sejarah kepemiluan mencatat bahwa tiap kali pileg selalu diawali perubahan atau penggantian undang-undang yang mengaturnya. Pileg pertama pada era ini, tahun 1999, diselenggarakan berdasarkan UU Nomor 3 Tahun 1999 tentang Pemilihan Umum (yang kemudian mengalami tiga kali perubahan) yang mengganti secara mendasar UU Nomor 15 Tahun 1969 tentang Pemilu Anggota Badan Permusyawaratan/Perwakilan Rakyat. Berikutnya undang-undang tersebut diganti dengan UU Nomor 12 Tahun 2003 tentang Pemilu Anggota DPR, DPD dan DPRD sebagai dasar penyelenggaraan pileg tahun 2004. Perkembangan berikutnya terbit UU Nomor 10 Tahun 2008 sebagai pengganti yang melandasi 
pileg tahun 2009 dan yang terakhir adalah UU Nomor 8 Tahun 2012 sebagai dasar penyelenggaraan pileg tahun 2104.

Sebagai produk kebijakan publik, undang-undang ini lahir atas dasar analisis mendalam terhadap permasalahan di mata publik terkait penyelenggaraan pileg khususnya tahap pencalonan pada periode sebelumnya. Untuk kepentingan ini, sebagai penyelenggara pileg, KPU menerbitkan Peraturan KPU (PKPU) Nomor 07 Tahun 2013 tentang Pencalonan Anggota DPR, DPRD Provinsi dan DPRD Kabupaten/Kota, yang kemudian diubah dengan PKPU Nomor 13 Tahun 2013. Dari perspektif kebijakan publik, terbitnya PKPU Nomor 07 Tahun 2013 ini merupakan bagian dari aktivitas interpretasi dalam tahap implementasi kebijakan, yaitu menjabarkan berbagai bahasa kebijakan sebagaimana tertuang dalam undang-undang menjadi rencana dan petunjuk teknis (juknis) yang siap dilaksanakan.

Dalam operasionalisasinya, hal ini kemudian diikuti oleh terbitnya berbagai surat edaran KPU berupa juknis untuk KPU Provinsi dan KPU Kabupaten/Kota yang melayani pendaftaran calon anggota DPRD. Dengan kata lain, dalam tahapan pencalonan anggota DPRD ini, KPU sebagai pembentuk PKPU berposisi sebagai policy maker, KPU Provinsi dan KPU Kabupaten/Kota sebagai policy implementor, serta pengurus parpol dan calon anggota DPRD berkedudukan sebagai policy target, baik yang masih bertugas sebagai anggota (incumbent/petahana) maupun yang akan mendaftar sebagai calon.

Karena itu, hadirnya berbagai kebijakan terkait pencalonan dalam pileg serta implementasinya oleh para agen pelaksana secara konsisten menjadi teramat penting. Dikatakan demikian karena ekspektasi publik untuk hadirnya penyelenggaraan pileg yang berkualitas dari waktu ke waktu makin tinggi. Sebagai misal, hal ini diantaranya bisa diketahui dari pemberitaan media masa baik jelang, pada saat maupun pascapenetapan daftar calon di berbagai daerah. Diantaranya berawal dari kekecewaan bakal calon dan parpol yang penyebabnya terkait dengan bermasalahnya beberapa aspek pengaturan pencalonan. Oleh karena itu, berbagai kebijakan KPU terkait pencalonan yang prokepentingan publik tentu akan berakibat meningkatnya kredibilitas dan akseptabilitas publik terhadap seluruh produk yang dihasilkannya.

Dalam konteks inilah evaluasi komprehensif terhadap aspek regulasi pencalonan dalam penyelenggaraan pileg ini dipandang sangat penting dilakukan. Penelitian ini bermaksud untuk mengelaborasi dan mengevaluasi lebih jauh berbagai aspek yang berkaitan dengan isi kebijakan (policy content) pencalonan anggota DPRD dalam penyelenggaraan pileg tahun 2014.

\section{B. METODE PENELITIAN}

Berdasarkan jenis dan fungsinya, penelitian ini menurut Marzuki (2015:47) tergolong penelitian hukum (legal research), atau penelitian hukum normatif atau hukum kepustakaan yang dilakukan dengan cara meneliti bahan pustaka atau data sekunder belaka (Soekanto dan Mamudji, 2015:13), atau penelitian perpustakaan dan dokumenter (Nazir, 2011:55). Selaras dengan tujuannya termasuk penelitian evaluasi dan berdasarkan sifat analisis datanya termasuk metode/pendekatan penelitian kualitatif, dengan teknik pengumpulan data studi dokumentasi dan kepustakaan. Penelitian dilakukan terhadap informasi yang didokumentasikan dalam bentuk peraturan sehingga biasa dikenal dengan penelitian analisis dokumen atau analisis isi (content analysis).

Sesuai dengan kepentingan penelitian ini, data yang bersifat sekunder berupa berbagai dokumen baik peraturan perundang-undangan, berbagai sumber literatur terkait tema penelitian, dokumen lain yang bersifat tercetak, termasuk surat kabar dan majalah dan sumber tercetak lain yang relevan, digunakan teknik studi dokumentasi. Terkait dengan ini, Nasution menyebutkan bahwa 'data dari 
sumber non manusia seperti dokumen, foto, dan bahan statistik dapat dipandang sebagai "narasumber" yang dapat diminta menjawab pertanyaan-pertanyaan yang diajukan oleh peneliti’ (1996:89).

Analisis data menurut Miles dan Huberman 'memiliki tiga alur kegiatan yang terjadi secara bersamaan, yaitu reduksi data, penyajian data dan penafsiran kesimpulan/verifikasi’ (1992:19). Teknik yang digunakan untuk menganalisis data sekunder adalah analisis isi (content analysis). 'Analisis ini digunakan untuk memperoleh keterangan dari semua bentuk isi komunikasi yang disampaikan dalam bentuk lambang, termasuk surat, peraturan dan undang-undang' (Rakhmat, 1997:1). Menurut B. Berelson, sebagaimana dikutip oleh Krippendorff, “analisis isi merupakan teknik penelitian untuk mendeskripsikan secara objektif, sistematik, dan kuantitatif isi komunikasi yang tampak (manifest)" (1993:16).

Mengacu kepada pendapat Wibawa, Howlett dan Ramesh serta sesuai dengan tujuan penelitian untuk menelaah isi kebijakan (policy content), maka dokumen yang menjadi fokus penelitian ini adalah UU Nomor 8 Tahun 2012, PKPU Nomor 07 Tahun 2013 dan perubahannya, PKPU lain yang terkait, serta juknis dalam bentuk Surat Edaran (SE) KPU yang berkaitan dengan kegiatan pencalonan anggota DPRD.

\section{KERANGKA TEORITIK}

\section{Demokrasi dan Pemilu}

Perbincangan berbagai kalangan khususnya penstudi ilmu politik ikhwal kosa kata demokrasi dan masa depannya tampaknya makin sering dan akan terus dilakukan. Hal ini sejalan dengan fakta bahwa demokrasi dan demokratisasi telah bermakna sangat luas dan berdimensi universalistik, yang gaungnya sangat terasa menembus ke berbagai dimensi kehidupan manusia. Meminjam istilah Huntington, dalam kehidupan umat manusia di muka bumi ini telah berlangsung apa yang disebutnya sebagai 'gelombang demokratisasi' (1995:13). Sebagai salah satu imbasnya, maka tatanan pemerintahan demokratis akan berkenaan dengan nilai-nilai (values) yang penting bagi kehidupan manusia serta berkaitan dengan prosedur untuk mewujudkan cita-citanya dalam kehidupan bernegara.

Dalam kaitan ini, Michael mengemukakan beberapa elemen pokok (key elements) demokrasi diantaranya 'recognition of rights for individuals, accountability of decision makers to the people, and representation' (2006:16). Tidak jauh beda, Henry B. Mayo menyebut beberapa nilai demokrasi, diantaranya "menyelesaikan perselisihan secara damai dan melembaga, menjamin terselenggaranya perubahan secara damai dalam suatu masyarakat yang sedang berubah, serta menyelenggarakan pergantian pimpinan secara teratur” (dalam Budiardjo, 2008:119). Kriteria demokrasi menurut Dahl antara lain adalah 'bahwa kendali atas keputusan-keputusan pemerintah mengenai kebijakannya berada pada pejabat-pejabat yang dipilih, dan pejabat-pejabat itu dipilih dalam pemilu yang dilangsungkan secara jujur dan bebas, secara praktis semua orang dewasa mempunyai hak untuk memilih, serta secara praktis semua orang dewasa mempunyai hak untuk dipilih sebagai pejabat dalam pemerintahan'(1994:94).

Sebagai fenomena universal, tentu saja demokrasi pun akan bersinggungan dengan negara atau pemerintahan. Dalam pandangan Michael, pemerintahan demokratis (democratic government) memiliki beberapa karakteristik diantaranya yaitu 'the rule of law-the same laws and the same judicial processes apply to all citizens; the principle of representation-the people who are subject to the laws must be equally represented in the legislative process that makes those laws; the institutionalisation of the process of government-in which functions are delineated, responsibilities are defined, and the mechanisms for change, including elections, are prescribed' (2006:31). Selaras dengan itu, Budiardjo mengemukakan ciri-ciri hakiki negara demokratis yaitu 
'negara hukum, kontrol efektif terhadap pemerintah, pemilu yang bebas, serta jaminan terhadap hak-hak demokratis’ (1999:58). Sebagai proses politik, pemilu (election, general election) sangat berkaitan dengan partai politik. Dalam konteks ini, Blondel menyebut bahwa 'parties are the main link between people and government in the contemporary world. Elections are the key mechanism of this link: they are the only way in which the bulk of the population can express its support for a party rather than another' (1995:180).

Dalam rumusan Mariana dan Paskarina, 'pemilu merupakan prasyarat dalam kehidupan bernegara dan bermasyarakat secara demokratis sehingga melalui pemilu sebenarnya rakyat sebagai pemegang kedaulatan akan memperbarui kontrak sosial; memilih pemerintahan baru; dan menaruh harapan baru dengan adanya pemerintahan baru’ (2008:5). Salah satu fungsi parpol di negara demokrasi adalah rekrutmen politik, dalam arti mempersiapkan kader terbaiknya untuk berjuang dalam kompetisi politik yang bernama pemilu sehingga mendudukkannya dalam berbagai jabatan publik. Terkait pemilu, Ball mengemukakannya sebagai 'the means by which the people choose and exercise some degree of control over their representatives' (1975:128).

Melalui mekanisme yang melahirkan para legislator inilah rakyat berperan penting dalam menentukan hitam putihnya negara. Dalam pandangan Surbakti, terdapat tiga hal dalam tujuan pemilu yaitu, 'Pertama, sebagai mekanisme untuk menyeleksi para pemimpin pemerintahan dan alternatif kebijakan umum. Kedua, sebagai mekanisme memindahkan konflik kepentingan dari masyarakat kepada badan-badan perwakilan rakyat melalui wakil-wakil rakyat yang terpilih atau melalui partaipartai yang memenangkan kursi sehingga integrasi masyarakat tetap terjamin. Ketiga, merupakan sarana memobilisasikan dan/atau menggalang dukungan rakyat terhadap negara dan pemerintahan dengan jalan ikut serta dalam proses politik' (1999:181).

Merujuk pada pandangan para ahli tersebut, tampak jelas bahwa pemilu merupakan salah satu karakteristik utama sekaligus instrumen sebuah negara yang menasbihkan dirinya sebagai negara demokrasi. Melalui pemilu inilah, rakyat memiliki momentum untuk menentukan pilihan politiknya kepada parpol tertentu untuk membentuk pemerintahan atau mengalihkan dan mempercayakannya kepada parpol lain. Secara konstitusional, di Indonesia hal ini termaktub dalam Pasal 1 ayat (2) UUD 1945 bahwa kedaulatan berada di tangan rakyat dan dilaksanakan berdasarkan konstitusi. Dalam percaturan kepemiluan ini, saat ini selain dikenal ada pemilu untuk memilih anggota DPR, DPD dan DPRD, dikenal pula sejak tahun 2004 ada pemilu untuk memilih presiden dan wakil presiden secara langsung oleh rakyat.

Aspek strategis lainnya dalam upaya mereformasi regulasi kepemiluan adalah berkenaan dengan penyelenggara pemilu. Hal ini tampak dalam UU Nomor 3 Tahun 1999 yang dalam Pasal 8 ayat (2) nya menegaskan bahwa penyelenggaraan pemilu dilakukan oleh Komisi Pemilihan Umum yang bebas dan mandiri, yang terdiri atas unsur partai-partai politik peserta pemilu dan pemerintah, yang bertanggung jawab kepada Presiden. Meskipun ketika itu dalam tubuh penyelenggara masih terdapat unsur parpolnya, tetapi paling tidak telah menunjukkan adanya upaya serius dalam membenahi organisasi perhelatan demokrasi lima tahunan ini. Kesungguhan ini makin diperkokoh dengan munculnya ketentuan Pasal 22 E ayat (5) UUD 1945 melalui amandemen ke -3 tahun 2001 yang telah memberikan salah satu watak penting bagi organisasi penyelenggara pemilu, yaitu "mandiri". Dikatakan demikian karena aspek kemandirian ini merupakan modal besar untuk terwujudnya pemilu yang kredibel dan akseptabel di mata publik.

Babak selanjutnya, sejarah juga mencatat terbitnya UU Nomor 12 Tahun 2003 yang dalam Pasal 15 ayat (1) nya menyebutkan bahwa pemilu diselenggarakan oleh KPU yang bersifat nasional, tetap dan mandiri. Hal ini lebih dipertajam lagi dalam undang-undang yang secara spesifik mengatur organisasi penyelenggara pemilu, yaitu UU Nomor 22 Tahun 2007 tentang Penyelenggara Pemilu, 
yang kemudian diganti dengan UU Nomor 15 Tahun 2011. Momentum ini diyakini sebagai salah satu penopang dan entry point terselenggaranya pemilu yang makin berkualitas. Secara eksplisit hal ini diantaranya tertuang dalam konsiderans “menimbang” huruf b undang-undang tersebut. Selain itu tergambar pula dalam ketentuan Pasal 1 angka 6 UU Nomor 22 Tahun 2007 bahwa KPU adalah lembaga penyelenggara pemilu yang bersifat nasional, tetap dan mandiri. Pasal 3 ayat (3) nya menyebutkan bahwa dalam menyelenggarakan pemilu, KPU bebas dari pengaruh pihak manapun berkaitan dengan pelaksanaan tugas dan wewenangnya. Hal yang sama ditegaskan juga dalam Pasal 1 angka 6 dan Pasal 3 ayat (3) UU Nomor 15 Tahun 2011 yang menggantikannya dan sampai dengan sekarang masih berlaku.

Salah satu tahapan penyelenggaraan pileg tahun 2014, berdasarkan ketentuan Pasal 4 ayat (2) UU Nomor 8 Tahun 2012 dari 11 tahapan penyelenggaraannya adalah pencalonan anggota DPR, DPD, DPRD provinsi, dan DPRD kabupaten/kota. Sebagai langkah penjabarannya, KPU menetapkan PKPU Nomor 07 Tahun 2012 tentang Tahapan, Program dan Jadwal Penyelenggaraan Pemilu Anggota DPR, DPD dan DPRD Tahun 2014. Secara garis besar tahapan dan jadwal pileg ini terdiri dari tiga tahapan besar yaitu tahapan persiapan, tahapan penyelenggaraan dan tahapan penyelesaian. Salah satu subtahapan dari 33 subtahapan dalam tiga tahapan pileg secara keseluruhan adalah pencalonan anggota DPR, DPD dan DPRD.

\section{Kebijakan Publik}

Di negara manapun, masyarakatnya akan dihadapkan pada aneka macam permasalahan yang tidak selamanya dapat mereka selesaikan sendiri. Ketika masalah itu lalu menjadi perhatian publik yang luas, menjadi perhatian dan agenda pemerintah, selanjutnya melalui serangkaian proses politik dan atau administratif diputuskan dan diikuti tindakan aktual untuk kepentingan publik, maka lahirlah kebijakan publik (public policy). Kebijakan publik menurut Gerston adalah 'the combination of basic decisions, commitments, and actions made by those who hold or influence government positions of authority' (2010:7). Post dkk. mengemukakannya sebagai 'a plan of action undertaken by government officials to achieve some broad purpose affecting a substansial segment of a nation's citizens' (1999:172).

Tidak jauh beda, dengan titik tekannya pada pilihan pemerintah, menurut Dunn adalah 'long series or more less related choices (including decision not to act) made by governmental bodies and officials, are formulated in issue areas which range from defence, energy and health to education, welfare and crime control'(1981:47). MacRae Jr. dan Wilde mendefinisikannya sebagai 'a policy made by government. Policy is a chosen course of significantly affecting large numbers of people’ (1985:3). Pakar kebijakan publik lainnya, Anderson menyebutkan bahwa kebijakan publik adalah 'those policies developed by governmental bodies and officials'. Nongovernmental actors and factors may, of course, influence policy development' (1978:3). Tampak bahwa negara atau pemerintah sangat strategis dalam pembentukan kebijakan publik ini. Hal ini sejalan dengan pandangan Michael bahwa 'without the existence of the state, the public policy making process, as we know it, could not operate. It is the state that provides the basis for collective decision making, the application and enforcement of those decisions, and the means for changing or altering others'(2006:11)

Terdapat lima komponen kebijakan publik menurut Gerston yaitu isu (issues), aktor (actor), sumberdaya (resource), lembaga (institution) dan tingkat pemerintahan (the level of government). Dikemukakan lebih lanjut bahwa 'issues that appear on the public agenda; actors who present, interpret, and respond to those issues; resources affected by those issues; institutions that deal with issues; and the levels of government that address issues' (2010:8). Untuk dapat 
memahami kebijakan publik secara utuh maka bisa dikenali dengan apa yang dinamakan Anderson sebagai kategori kebijakan, yaitu 'policy demands, policy decisions, policy statements, policy output dan policy outcome’ (1978:4).

Berdasarkan pandangan para pakar tersebut, maka kebijakan publik merupakan serangkaian keputusan yang ditetapkan oleh pejabat dan atau lembaga negara/pemerintah yang sebelumnya melibatkan berbagai pihak dan dilanjutkan dengan tindakan nyata sesuai dengan kewenangan yang dimiliki untuk menangani masalah publik. Dalam konteks kepemiluan, salah satu bentuk atau wujud kebijakan publik tersebut adalah UU Nomor 8 Tahun 2012 beserta PKPU turunannya yaitu PKPU Nomor 07 Tahun 2012, PKPU Nomor 11 Tahun 2012, PKPU Nomor 07 Tahun 2013 dan PKPU Nomor 13 Tahun 2013. Dikatakan demikian karena kesemuanya lahir dari kewenangan lembaga publik dalam hal ini DPR, Presiden dan KPU untuk menangani masalah publik berkenaan dengan berbagai tuntutan dan harapan terkait pencalonan dalam penyelenggaraan pileg.

\section{Evaluasi Kebijakan}

Dengan menggunakan model proses untuk mendapatkan pemahaman yang utuh tentang kebijakan publik, tampak jelas bahwa ia merupakan proses yang kompleks dan melibatkan banyak aktor, baik pada institusi masyarakat maupun negara/pemerintah. Salah satu tahapannya adalah evaluasi kebijakan (policy evaluation) yang menurut Gerston 'assesses the effectiveness of a public policy in terms of its perceived intentions and results'(2010:112). Tahapan ini oleh Jones didefinisikan sebagai 'an activity designed to judge the merits of government programs or processes. It varies in the specification of criteria, the techniques of measurement, the methods of analysis, and the forms of recommendation'(1984:199).

Tahapan lain dalam keseluruhan siklus atau proses kebijakan publik selain evaluasi kebijakan menurut Howlett adalah 'agenda setting, policy formulation, decision making, dan policy implementation' (2011:19), sedangkan menurut Anderson adalah 'problem formation, formulation, adoption, dan implementation' (1978:23). Dengan rumusan yang tidak begitu beda, Dye mengemukakan adanya tahapan 'the identification of policy problems, the formulation of policy proposals, the legitimation of policies, the implementation of policies dan the evaluation' (1987:324).

Evaluasi kebijakan sebagai bagian integral dari siklus kebijakan publik berperan sangat strategis bagi upaya untuk mengetahui pencapaian kinerja organisasi. Adanya tahap ini bermakna sangat penting karena belum tentu sasaran akhir dari suatu kebijakan atau program publik dapat tercapai secara efektif. Berbagai harapan ideal sebagaimana telah dirumuskan pada saat penetapan kebijakan akan diketahui tingkat ketercapaiannya dengan tahapan evaluasi ini. Dengan kata lain, bagi perumus kebijakan dan implementor kebijakan sangat diperlukan informasi tentang kinerja kebijakan sebagai sarana untuk perbaikan pada siklus kebijakan secara keseluruhan.

Dalam pandangan Wibawa, 'evaluasi kebijakan bermaksud untuk mengetahui empat aspek, yaitu proses pembuatan kebijakan, proses implementasi, konsekuensi kebijakan dan efektivitas dampak kebijakan. Keempat aspek ini dapat mendorong seorang evaluator untuk secara khusus mengevaluasi isi kebijakan, baik pada dimensi hukum dan terutama kelogisannya dalam mencapai tujuan, maupun konteks kebijakan, kondisi lingkungan yang mempengaruhi seluruh proses kebijakan' (1994:9). Merujuk kepada Howlet dan Ramesh, evaluasi proses (process evaluation) merupakan salah satu tipe dari lima tipe evaluasi administratif (administrative evaluation) yaitu 'examine the organizational methods, including rules and operating procedures, used to deliver programs' (1995:171). 
Dengan demikian tampak jelas betapa penting dan strategisnya peran evaluasi kebijakan dalam keseluruhan proses kebijakan publik, termasuk dalam urusan kepemiluan. Kegiatan ini tidak hanya harus dilakukan oleh unsur-unsur penyelenggara pemilu, tetapi juga oleh kalangan lain yang memiliki kepedulian pada hajat demokrasi lima tahunan ini. Dengan kata lain, pemerintah, DPR dan KPU akan sangat terbantu dengan adanya evaluasi kebijakan yang melibatkan para stakeholder pemilu yang lain atau menerima masukan hasil evaluasi yang secara mandiri telah mereka lakukan. Banyak aspek yang dapat dievaluasi, dan salah satunya dapat berbentuk evaluasi secara khusus terhadap substansi kebijakan kepemiluan.

\section{D. hasil dan PEMBAHASAN}

\section{Hirarki dan Konteks Kebijakan}

UU Nomor 8 Tahun 2012 lahir sebagai derivasi dari ketentuan Pasal 22 E UUD 1945 yang mengatur tentang pemilu. Mengadopsi pandangan Bromley (1989:32-33) ia berada pada policy level, selanjutnya dijabarkan dalam PKPU Nomor 07 Tahun 2013 yang berada pada organizational level yang mengalami perubahan dengan terbitnya PKPU Nomor 13 Tahun 2013. Sesuai kewenangannya, pada operational level KPU menerbitkan juknis diantaranya SE Nomor 225/ KPU/IV/2013 tentang Petunjuk Teknis Tata Cara Pencalonan Anggota DPR, DPD dan DPRD dan SE Nomor 315/KPU/V/2013 tentang Temuan Hasil Verifikasi Administrasi Pemenuhan Syarat Pengajuan Bakal Calon dan Syarat Bakal Calon Anggota DPRD.

Undang-undang ini merupakan bagian penting dari upaya peningkatan kualitas penyelenggaraan pileg. Hal ini dapat diketahui dalam penjelasan umumnya bahwa upaya memperbaiki penyelenggaraan pemilu ini merupakan bagian dari proses penguatan dan pendalaman demokrasi (deepening democracy) serta upaya mewujudkan tata pemerintahan presidensiil yang efektif. Dari perspektif hirarki kebijakan publik, terbitnya undang-undang ini merupakan pedoman dasar bagi regulasi pileg yang ditetapkan penyelenggara dan mengikat semua stakeholders. Selain itu selaras pula dengan prinsip hierarki sebagaimana diatur dalam Pasal 7 ayat (2) UU Nomor 12 Tahun 2011 tentang Pembentukan Peraturan Perundang-undangan bahwa penjenjangan setiap jenis peraturan perundangundangan yang didasarkan pada asas bahwa peraturan perundang-undangan yang lebih rendah tidak boleh bertentangan dengan peraturan perundang-undangan yang lebih tinggi. Hal ini sejalan pula dengan yang dikemukakan pakar kebijakan publik, Anderson, bahwa salah satu ciri kebijakan publik adalah 'in its positive form is based on law and is authoritative’ (1978:4).

Terbitnya PKPU Nomor 07 Tahun 2013 merupakan sesuatu yang imperatif berdasarkan dua undang-undang. Pertama, untuk melaksanakan ketentuan Pasal 8 ayat (1) huruf c UU Nomor 15 Tahun 2011 bahwa tugas dan wewenang KPU adalah menyusun dan menetapkan pedoman teknis untuk setiap tahapan pemilu. Kedua, untuk melaksanakan ketentuan Pasal 59 ayat (3) dan Pasal 67 ayat (3) UU Nomor 8 Tahun 2012 bahwa KPU harus menetapkan PKPU tentang pencalonan. Diubahnya PKPU Nomor 07 Tahun 2013 dengan PKPU Nomor 13 Tahun 2013 ini dari perspektif analisis kebijakan publik merupakan respon penyelenggara pileg terhadap dinamika perkembangan lingkungan baik yang berada pada tataran pemerintahan maupun masyarakat.

Terbitnya SE Nomor 225/KPU/IV/2013 secara ideal merupakan derivasi dari PKPU Nomor 07 Tahun 2013 sehingga secara hirarkis tidak bertentangan dengan PKPU Nomor 07 Tahun 2013 apalagi dengan UU Nomor 8 Tahun 2012. SE Nomor 315/KPU/V/2013 merupakan langkah responsif KPU terhadap dinamika perkembangan yang terjadi pada pemangku kepentingan pemilu sebagai policy target sekaligus sebagai lingkungan kebijakan (policy environment). Direvisinya kedua regulasi tersebut menunjukkan interaksi antara institusi publik dengan lingkungannya, dan hal 
ini sejalan dengan apa yang dijelaskan Robert Eyestone bahwa kebijakan publik sebagai "the relationship of a government unit to its environment" (dalam Anderson, 1978:2).

Ini sejalan dengan yang dikemukakan Dye tentang sistem kebijakan (The Policy System) sebagai 'the relationships or linkages between social and economic conditions, characteristic of political systems, and the content of public policy' (1987:6). Terbitnya UU Nomor 8 Tahun 2012, PKPU terkait jadwal dan pencalonan, serta beberapa SE yang pada dasarnya wujud kebijakan publik (Public Policy) merupakan respon terhadap lingkungan kebijakan (Society/Social and Economic Conditions/Environmental Forces and Conditions) berupa kondisi makin kritisnya masyarakat terhadap regulasi kepemiluan. Sebaliknya terbitnya berbagai regulasi itupun akan mempengaruhi lingkungan kebijakan.

Terbitnya semua regulasi tersebut karena peran para pemangku kepentingan (stakeholders) pileg, baik institusi maupun aktor-aktor negara/pemerintah (governmental actors) seperti pejabat negara, legislator, aparat penyelenggara pemilu, birokrat pemerintah serta aktor di masyarakat (nongovernmental actor), yang semuanya berada pada sistem politik (Political System/ Political and Governmental Institutions, Processes, and Behaviors). Kedudukan KPU sebagai penyelenggara pemilu yang dalam konteks sistem kebijakan merupakan bagian dari sistem politik diatur tugas, wewenang dan kewajibannya dalam UU Nomor 15 Tahun 2011. Diantara regulasi kepemiluan sebagai kebijakan publik dengan sistem politik ini terjadi hubungan saling pengaruh mempengaruhi. Secara skematis, hal tersebut dapat terlihat pada gambar berikut :

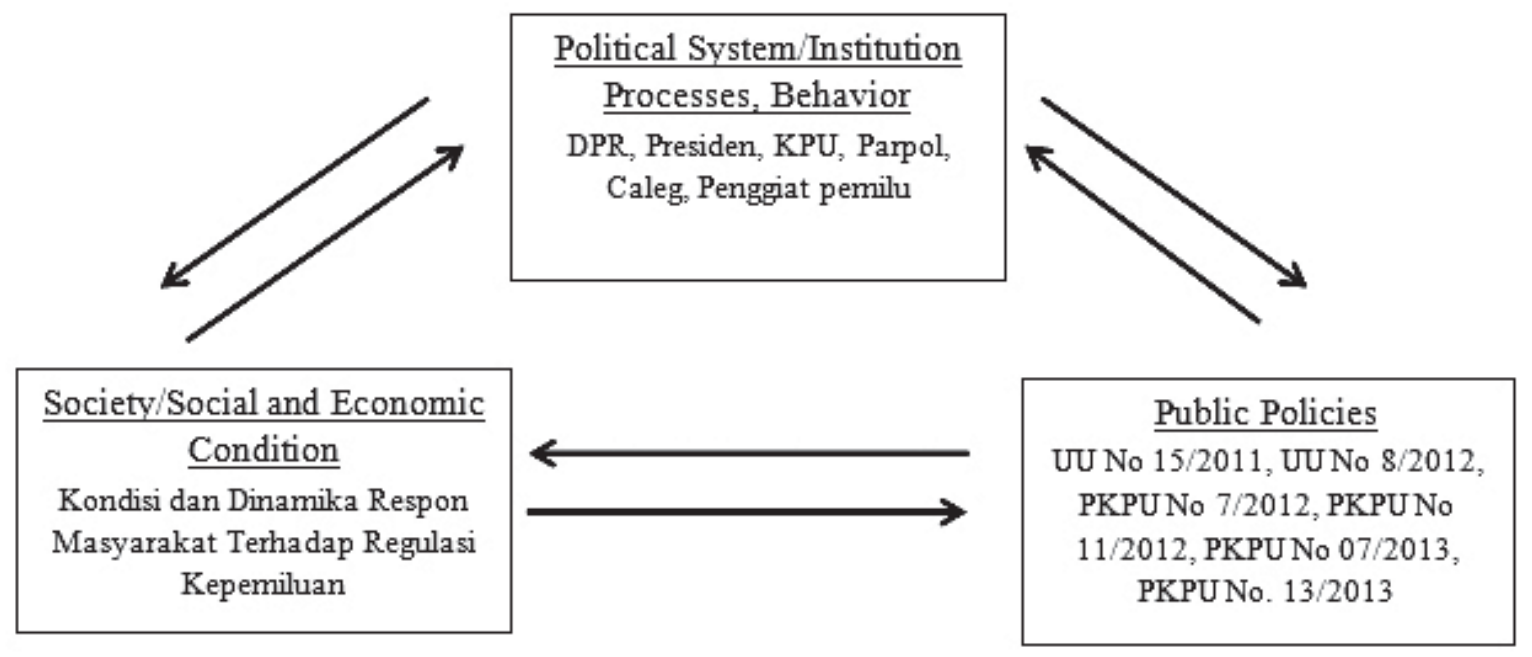

Sumber : Adaptasi dari Dye (1987:6)

Gambar 1.

Regulasi Pencalonan Dalam Sistem Kebijakan

Mengacu dan mengadopsi pandangan Bromley (1980:32-33), maka hadirnya UU Nomor 15 Tahun 2011 dan UU Nomor 8 Tahun 2012 merupakan produk kebijakan pada policy level, sedangkan PKPU Nomor 7 Tahun 2012, PKPU Nomor 11 Tahun 2012, PKPU Nomor 07 Tahun 2013 dan PKPU Nomor 13 Tahun 2013 berada pada organizational level. Pada operational level terdapat SE Nomor 225/KPU/IV/2013 dan SE Nomor 315/KPU/V/2013. Dalam implementasinya, semua produk kebijakan tersebut menimbulkan pola-pola interaksi yang berlangsung pada tataran pelaksana kebijakan dan pada publik sebagai target kebijakan. Pada fase ini tentu akan banyak catatan berharga tentang berbagai aspek implementasi kebijakan pencalonan yang disampaikan para target kebijakan kepada penyelenggara. Salah satu catatan masukan tersebut 
berkenaan dengan prosedur dan substansi pencalonan dalam penyelenggaraan pileg. Selanjutnya, dilakukan penilaian saksama terhadap aspek implementasinya termasuk masukan dari para pemangku kepentingan pemilu sebagai dasar penyempurnaan kebijakan di masa yang akan datang.

Secara skematis, hirarki dan proses kebijakan pencalonan dalam pileg ini dapat divisualisasikan sebagai berikut :

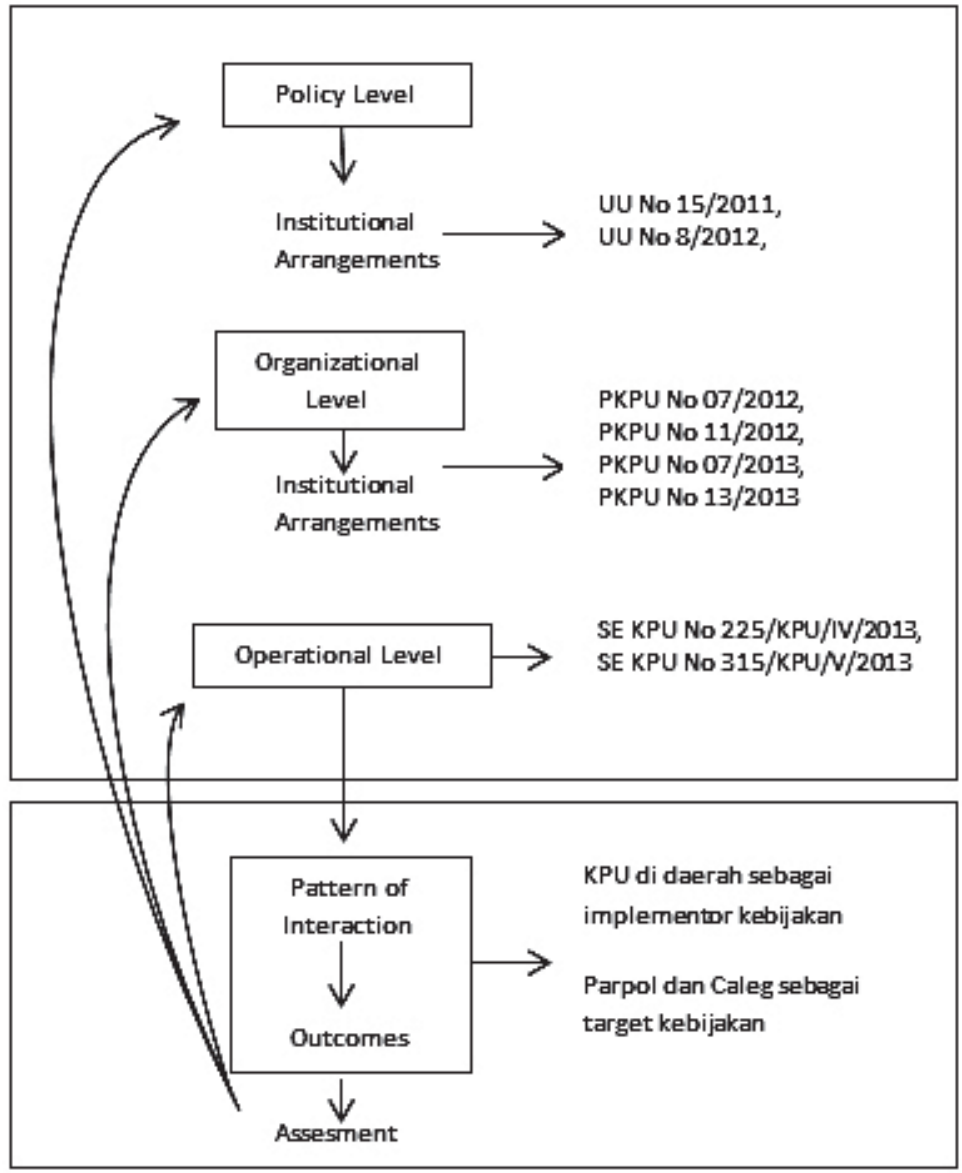

"Level Atas"

"Level Bawah"

Sumber : Adaptasi dari Bromley (1989:32-33)

Gambar 2.

Hirarki Kebijakan Pencalonan Dalam Pileg

\section{Substansi Kebijakan}

Dalam UU Nomor 8 Tahun 2012, PKPU Nomor 07 Tahun 2013, serta dua SE KPU sebagai kebijakan pencalonan dalam pileg terdapat beberapa terma atau frasa yang tidak jelas, multiinterpretatif, kontradiktif/tidak konsisten dan tidak operasional/tidak implementatif.

Substansi kebijakan yang tidak jelas adalah sebagai berikut:

a. Pasal 51 ayat (1) huruf h UU Nomor 8 Tahun 2012 tentang sehat jasmani dan rohani. Dalam penjelasan pasal tersebut tidak jelas kaitannya dengan bila surat kesehatan atau surat keterangan sehat tersebut dikeluarkan oleh dokter pemerintah (dokter PNS, dokter anggota TNI/Polri) yang berpraktek swasta di luar jam kerja (pagi,sore,malam hari). Kenyataannya cukup banyak calon anggota DPRD mendapatkan surat keterangan sehat tersebut dari dokter PNS yang berpraktek swasta pada pagi, sore atau malam hari. 
b. Frasa "rumah sakit pemerintah" pada Penjelasan Pasal 51 ayat (1) huruf h tidak menyebutkan meskipun hanya sebagai contoh rumah sakit seperti apa saja yang termasuk ketegori rumah sakit pemerintah. Misalnya di beberapa kota terdapat rumah sakit milik TNI dan Polri dengan unit/instalasinya yang dalam beberapa hal terdapat perbedaan terkait kriteria sehat jasmani dan rohani sebagaimana dipersyaratkan. Demikian pula frasa "rumah sakit pemerintah" pada Pasal 19 huruf f PKPU Nomor 07 Tahun 2013 tidak menjelaskan fakta tersebut. Untuk menghindari kemungkinan beda tafsir di kalangan pelaksana pileg di daerah, mestinya ketentuan PKPU ini mengakomodasi hal tersebut. Potensi multitafsir ini tampak pula dalam SE Nomor 225/KPU/ IV/2013 dan Nomor 315/KPU/V/2013. Kekuranglengkapan informasi ini merupakan sesuatu yang kontradiktif pada suatu kebijakan derivatif yang seharusnya lebih teknis, detail dan operasional dibandingkan dengan undang-undang yang mendasarinya. Terkait dengan hal ini, Edwards III menegaskan bahwa 'orders to implement policies must be transmitted to the appropriate personnel, and they must be clear, accurate, and consistent' (1989:10).

c. Penjelasan Pasal 51 ayat (1) khususnya terkait dengan institusi pemberi surat kesehatan/surat keterangan sehat, tidak menyebutkan tentang Dinas Kesehatan di beberapa kota/kabupaten yang juga memiliki unit/instalasi kesehatan relatif lengkap yang dalam kenyataannya melayani masyarakat sebagaimana rumah sakit pada umumnya. Hal ini menimbulkan tanda tanya aparat pelaksana pileg dalam memverifikasi berkas persyaratan, sehingga menjadi ganjalan dalam berkomunikasi dengan pengurus parpol dan caleg yang bersangkutan. Hal yang sama tidak mendapatkan penjelasan memadai dalam Pasal 19 huruf f PKPU Nomor 07 Tahun 2013 serta dalam SE Nomor 225/KPU/IV/2013. Padahal semestinya dalam kedua regulasi terbitan KPU itu diatur tentang hal tersebut sehingga menjadi panduan yang jelas bagi penyelenggara di daerah serta bagi pengurus parpol dan caleg masing-masing.

d. Pasal 19 huruf f PKPU Nomor 07 Tahun 2013. Sebagai derivasi dari UU Nomor 8 Tahun 2012, seharusnya PKPU ini mengatur secara memadai berbagai kemungkinan yang muncul terkait dengan kedudukan dokter pemerintah yang memegang peran-peran lain dalam praktek kedokteran. Ketidakjelasan ini terdapat pula dalam SE Nomor 225/KPU/IV/2013. Padahal untuk efektifnya implementasi kebijakan pencalonan sangat diperlukan adanya policy content yang jelas dan tidak multiinterpretatif. Dalam kaitan ini, Jones menyebut bahwa salah satu tahap penting dalam implementasi kebijakan atau program adalah interpretation yaitu 'the translation of program language (often contained in an statute) into acceptable and feasible plans and directives' (1984:166).

e. Pada Lampiran I PKPU Nomor 07 Tahun 2013 tentang model BB 12 contoh berita acara hasil verifikasi huruf g tidak disebutkan secara eksplisit bahwa surat keterangan tidak terkena/bebas narkoba tersebut berasal dari dokter rumah sakit pemerintah, karena dalam faktanya ada bakal calon yang mendapatkan surat keterangan tersebut dari dokter rumah sakit swasta. Lampiran I PKPU Nomor 07 Tahun 2013 tentang model BB 12 contoh berita acara hasil verifikasi tidak disebutkan/tidak ada kolom/lajur keberadaan 4 (empat) formulir/surat keterangan yaitu surat keterangan dari PPS bahwa telah terdaftar, surat keterangan tentang sehat jasmani dan rohani, surat keterangan tentang tidak terkena/bebas narkoba serta surat keputusan pemberhentian atau surat keterangan persetujuan pengunduran diri dari pejabat yang berwenang. Sebagai bagian penting dari regulasi kepemiluan, tentu keberadaan formulir/dokumen yang jelas dan lengkap sangat diperlukan oleh para verifikator berkas persyaratan di setiap daerah. 
Kemudian substansi kebijakan yang multi-interpretatif adalah sebagai berikut:

a. Penjelasan Pasal 51 ayat (1) huruf h UU Nomor 8 Tahun 2012 terkait frasa "dari dokter, puskesmas, atau rumah sakit pemerintah yang memenuhi syarat". Terma "yang memenuhi syarat" bermakna beraneka ragam karena dalam kenyataannya kapasitas/fasilitas medis puskesmas atau rumah sakit di setiap daerah tidak sama.

b. Pasal 19 huruf f PKPU Nomor 07 Tahun 2013. Seyogianya dalam Penjelasan Pasal 51 tersebut dan atau dalam PKPU Nomor 07 Tahun 2013 tersebut hal itu benar-benar diatur secara rinci dan jelas sesuai dengan regulasi bidang kesehatan sehingga tidak menimbulkan kebingungan pengurus parpol, caleg dan pelaksana pileg.

c. Penjelasan Pasal 51 ayat (1) huruf h tentang surat kesehatan atau surat keterangan sehat dimaknai oleh beberapa kalangan penyelenggara pileg di daerah sebagai sehat jasmani dan rohani berdasarkan hasil pemeriksaan kesehatan secara menyeluruh (general check up) sebagaimana pernah diberlakukan pada pemilu tahun 2004 dan 2009. Kondisi ini merupakan sesuatu yang tidak positif bagi implementasi kebijakan, karena dalam kenyataannya terdapat variasi surat keterangan yang dimiliki oleh setiap caleg. Ada caleg yang menunjukkan surat keterangan dari puskesmas atau rumah sakit pemerintah (umumnya dari rumah sakit) dengan jenis pemeriksaan jasmani/fisik yang sangat lengkap (general chek up), termasuk pemeriksaan rohani dengan biaya hampir Rp 1 juta bahkan dengan melampirkan bukti pemeriksaannya. Sebaliknya ada juga caleg yang menunjukkan surat keterangan dari puskesmas tingkat kecamatan yang berupa pemeriksaan sangat sederhana, tanpa melampirkan bukti hasil pemeriksaan dan dengan biaya tidak sampai Rp 50 ribu. Hal yang sama muncul dalam ketentuan Pasal 19 huruf f PKPU Nomor 07 Tahun 2013 dan tidak dijelaskan pula dalam SE Nomor 225/KPU/IV/2013. Padahal seharusnya dalam kedua regulasi tersebut tertuang penjelasan yang rinci, jelas, komprehensif dan implementatif.

d. Frasa "badan lain yang anggarannya dari keuangan negara” pada Pasal 51 ayat (1) huruf k menimbulkan multitafsir bukan hanya di kalangan bakal calon dan pengurus parpol tetapi juga penyelenggara pileg di daerah. Misalnya terkait dengan adanya bakal calon yang merupakan/ menjabat anggota/pengurus Komite Olahraga Nasional Indonesia (KONI) daerah, Badan Permusyawaratan Desa (BPD) dan Lembaga Pemberdayaan Masyarakat (LPM) mengingat anggaran ketiganya bersumber dari APBD. Hal ini pun tidak mendapatkan penjelasan memadai dalam Pasal 4 huruf k PKPU Nomor 07 Tahun 2013. Padahal seharusnya Pasal 4 huruf k ini memberikan norma yang lebih operasional dengan memberikan contoh seperti demikian karena anggarannya bersumber dari APBD. Situasi multiinterpretatif muncul pula karena tidak mendapatkan penjelasan yang memadai dalam SE Nomor 225/KPU/IV/2013 dan SE Nomor 315/KPU/V/2013.

e. Frasa “..serta pekerjaan lain yang dapat menimbulkan konflik kepentingan..” sebagaimana tercantum dalam Pasal 51 ayat (1) huruf 1 sangat membuka peluang terjadinya interpretasi yang beragam. Pengurus parpol, caleg dan aparat pelaksana pileg interpretasinya beragam ketika hal ini tidak dijelaskan pula dalam PKPU Nomor 07 Tahun 2013 dan SE Nomor 225/KPU/ IV/2013.

f. Frasa “..yang sudah mengundurkan diri..” pada penjelasan Pasal 51 ayat(2)huruf i menimbulkan multitafsir. Ini terkait dengan adanya tiga kemungkinan waktu mundurnya yang bersangkutan, diantaranya adalah pada saat bakal calon yang bersangkutan membuat surat pernyataan mundur sebagai PNS. Atau bisa juga pada saat pejabat/atasan langsung yang bersangkutan membuat surat keterangan bahwa memberikan persetujuan pengunduran diri yang bersangkutan sebagai PNS dan surat keputusan pemberhentiannya sebagai PNS akan diproses. Selain itu, mungkin 
juga pada saat surat keputusan pemberhentiannya sebagai PNS sudah terbit. Hal ini perlu dipertegas karena berkaitan dengan statusnya sebagai PNS yang terikat pada berbagai peraturan kepegawaian negara. Pemahaman yang multiinterpretatif ini tentu saja tidak mendukung implementasi kebijakan pencalonan yang efektif.

Selanjutnya, substansi kebijakan yang kontradiktif atau tidak konsisten adalah sebagai berikut:

a. Frasa “pejabat negara lainnya” pada Pasal 51 ayat (1) huruf m UU Nomor 8 Tahun 2012 tidak tepat karena anggota DPRD (Provinsi dan Kabupaten/Kota) menurut peraturan perundangundangan yang berlaku tidak termasuk kategori pejabat negara.

b. Frasa “pejabat negara lainnya” pada Pasal 4 huruf m PKPU Nomor 07 Tahun 2013. Seharusnya sebagai bagian dari sistem kebijakan publik nasional yang terikat dengan regulasi dalam sistem hukum nasional, UU Nomor 8 Tahun 2012 dan PKPU ini sejauh mungkin konsisten terhadap peraturan perundang-undangan yang berlaku. Menurut ketentuan beberapa UU, anggota DPRD tidak disebut sebagai pejabat negara, diantaranya dalam Pasal 11 UU Nomor 8 Tahun 1974 tentang Pokok-pokok Kepegawaian, Pasal 11 ayat (1) UU Nomor 43 Tahun 1999 tentang Perubahan Atas UU Nomor 8 Tahun 1974, serta Pasal 2 UU Nomor 28 Tahun 1999 tentang Penyelenggara Negara Yang Bersih dan Bebas dari KKN. Demikian pula dalam ketentuan Pasal 122 UU Nomor 5 Tahun 2014 tentang Aparatur Sipil Negara yang terbit setelah proses pencalonan selesai serta mengganti UU Nomor 8 Tahun 1974 dan UU Nomor 43 Tahun 1999, tidak menyebutkan bahwa anggota DPRD berkedudukan sebagai pejabat negara.

c. Pada Pasal 29 ayat 2 tertulis di ujung kalimat "bakal calon”, padahal nama-nama yang tercantum dalam daftar sudah merupakan calon, bukan lagi bakal calon, sehingga disebutnya sesuai judul babnya adalah Daftar Calon Sementara dan Daftar Calon Tetap. Secara mendasar jelas sangat berbeda pengertian dari “calon” dengan "bakal calon”. Dengan mengacu pada pandangan Anderson bahwa kebijakan publik itu based on law dan bersifat otoritatif, maka penulisan yang tidak konsisten pada ketentuan pasal tersebut tentu merupakan sesuatu yang kontraproduktif bagi implementasi kebijakan yang efektif.

d. Inkonsistensi berkaitan dengan frasa "surat pernyataan pengunduran diri" sebagaimana tersebut pada Pasal 19 huruf i dengan Lampiran I terkait jenis formulir nomor 7 (model BB 4) dan lampiran contoh model BB 4. Tentu berbeda makna dari frasa "surat pernyataan pengunduran diri" sebagaimana tersebut pada Pasal 19 huruf i dengan frasa "surat pernyataan tentang kesediaan mengundurkan diri..” sebagaimana tersebut pada Lampiran I nomor 7 (model BB 4) dan frasa “..saya telah mengundurkan diri..”sebagaimana tersebut dalam Lampiran I tentang contoh model BB 4. Sebagai bagian integral dari kebijakan pencalonan pileg, terlebih-lebih karena berbentuk juknis maka seyogianya terdapat keseragaman redaksional karena akan membawa konsekuensi yang sangat luas terhadap gerak langkah penyelenggara pileg di daerah ketika melakukan verifikasi dokumen persyaratan.

e. Frasa "masa berlaku ijazah tidak dibatasi” pada Lampiran 1 Huruf B angka 2 huruf d angka (5) berpotensi membingungkan penyelenggara pileg yang melakukan verifikasi. Karena dokumen yang namanya ijazah tentu saja memiliki daya berlaku selamanya, berbeda dengan daya berlaku legalisasi fotocopi ijazah. Tentu berbeda pula antara ijazah dengan fotocopi ijazah, sehingga oleh karenanya yang dimaksudkan frasa tersebut adalah masa berlaku fotocopi ijazah bukan masa berlaku ijazah. Konsistensi peristilahan yang saling berkaitan antara naskah dengan lampiran tentu merupakan hal yang sangat penting bagi sebuah dokumen kebijakan. 
Dan substansi kebijakan yang tidak operasional/tidak implementatif adalah sebagai berikut:

a. Dalam Pasal 6 PKPU Nomor 07 Tahun 2013 ini terdapat substansi bermasalah diantaranya tentang ijazah/STTB terkait dengan pemenuhan persyaratan pendidikan paling rendah tamat sekolah menengah atas, madrasah aliyah, sekolah menengah kejuruan, madrasah aliyah kejuruan, atau pendidikan lain yang sederajat. Ketentuan pasal ini tidak menyebut dan membedakan keberadaan ijazah/STTB dari institusi pendidikan negeri dan swasta sebagaimana diatur dalam ketentuan Pasal 8 tentang ijazah dari perguruan tinggi. Padahal di masa sebelum tahun 1990 an masih dikenal adanya ijazah negara yang diberikan kepada siswa SLTA dari sekolah swasta yang telah lulus ujian negara. Ijazah itulah yang resmi diberikan oleh pemerintah saat itu dan memiliki civil effect untuk berbagai kepentingan, termasuk menjadi salah satu syarat menjadi pegawai pemerintah. Pada saat yang sama masing-masing sekolah swasta tersebut mengeluarkan juga ijazah yang diberikan kepada siswa yang telah lulus ujian di sekolah tersebut tetapi belum lulus dalam ujian negara, yang sering dinamakan sebagai ijazah lokal. Faktanya ditemukan beberapa ijazah yang termasuk kategori ijazah lokal tersebut sehingga perlu diklarifikasi ke Dinas Pendidikan atau Kantor Kementerian Agama setempat. Secara substantif tentu pengaturan yang sangat rinci dalam PKPU selaras dengan level kebijakannya sebagai derivasi dari undangundang sangat diperlukan sehingga menjadi panduan yang jelas bagi implmentor kebijakan pencalonan di KPU Provinsi dan KPU Kabupaten/Kota.

b. Pasal 8 ayat (1) huruf a hanya mengatur keberadaan ijazah dari perguruan tinggi negeri, yang dimaknai oleh berbagai pihak sebagai ijazah yang dikeluarkan oleh perguruan tinggi negeri yang bernaung di bawah departemen (sekarang kementerian) Pendidikan dan Kebudayaan dan Departemen Agama. Padahal faktanya ada bakal calon lulusan perguruan tinggi kedinasan, yaitu yang dikelola oleh departemen di luar Departemen Pendidikan dan Kebudayaan dan Departemen Agama, serta yang dikelola oleh lembaga pemerintah nondepartemen. Bakal calon yang bersangkutan maju dalam pencalonan setelah pensiun dari instansi pemerintah tempatnya bekerja. Dengan demikian keluasan informasi yang sangat memadai sangat diperlukan dalam regulasi selevel PKPU yang seharusnya sangat teknis, operasional dan implementatif.

c. Pasal 8 ayat (1) huruf b mengatur keberadaan ijazah dari perguruan tinggi swasta yang diterbitkan oleh pimpinan perguruan tinggi. Ketentuan pasal ini tidak menyebut keberadaan ijazah yang diterbitkan oleh masing-masing perguruan tinggi swasta sebelum tahun 1998 yang diberikan kepada lulusannya setelah menempuh dan lulus ujian. Ijazah tersebut lazim dinamakan sebagai ijazah lokal, karena yang bersangkutan belum lulus mata kuliah ujian negara yang diselenggarakan Koordinasi Perguruan Tinggi Swasta (Kopertis) sehingga oleh karenanya tidak atau belum memiliki ijazah yang telah ditandasahkan oleh Kopertis setempat, yang lazim dinamakan sebagai ijazah negara. Ijazah negara inilah yang resmi disahkan dan diakui negara/pemerintah sehingga oleh karenanya memiliki civil effect dan menjadi salah satu syarat seseorang melamar jadi pegawai pemerintah. Meskipun anggota DPRD bukan jabatan birokrasi pemerintahan (appointed officials) tetapi jabatan politik (elected officials) tetapi berkenaan dengan pengaturannya yang bersifat rinci dan operasional tentu saja sangat dibutuhkan bukan hanya oleh kalangan parpol dan bakal caleg tetapi juga oleh perangkat penyelenggara yang melayani pencalonan di daerah.

d. Pasal 14 menyebutkan bahwa untuk keperluan pencalonan, pimpinan parpol sesuai tingkatannya menetapkan 2 (dua) orang pengurus parpol sebagai petugas penghubung antara parpol dengan penyelenggara. Ketentuan ini tidak mengatur lebih lanjut kewenangan dari petugas penghubung ini, termasuk tidak juga diatur lebih lanjut dalam dua SE KPU yang terbit kemudian. Ketika petugas penghubung ini berinteraksi dengan penyelenggara di tingkat daerah sangat diperlukan 
adanya kejelasan dan ruang lingkup wewenang yang melekat pada penugasannya. Edwards III dalam kaitan ini mengingatkan pentingnya kewenangan (authority) sebagai salah satu unsur dari sumberdaya (resources) bahwa 'the authority to ensure that policies are carried out as they are intended' (1989:11).

e. Pasal 4 huruf k tentang pengunduran diri dari beberapa jabatan/kedudukan yang berkaitan dengan ketentuan Pasal 9 ayat (1) dan ayat (2) dan Pasal 19 huruf i angka 1 dan 4 berpotensi merepotkan penyelenggara. Hal ini antara lain karena surat pemberhentian sebagai PNS dari pejabat yang berwenang memakan waktu cukup lama, apalagi untuk PNS golongan IV yang harus dari instansi pusat, sehingga berpotensi melampaui batas waktu penyerahan dokumen sebagaimana tertuang dalam Pasal 21 ayat (1). Demikian pula surat keputusan pemberhentian dari pejabat berwenang sebagaimana dimaksud Pasal 9 ayat (1) dan atau surat keterangan dari atasan langsung sebagaimana dimaksud Pasal 9 ayat (2) berpotensi memakan waktu lama atau dibuat lama bila PNS bakal calon yang bersangkutan berasal dari parpol yang berbeda dengan kepala daerah yang bersangkutan. Hal yang sama juga sangat berpotensi terjadi untuk bakal calon yang merupakan kepala desa dan atau perangkat desa sebagaimana diatur dalam Pasal 19 huruf i angka 4. Dengan kata lain, sebagai panduan implementatif, seyogianya PKPU ini mampu memberikan gambaran yang jelas tentang kerangka waktu yang rasional dikaitkan dengan jadwal pileg secara keseluruhan.

f. Dalam SE Nomor 225/KPU/IV/2013 masih terdapat beberapa ketentuan tentang berbagai aspek pencalonan yang tidak bersifat teknis. Padahal sebagai produk kebijakan yang berada pada operational level (Bromley, 1989:32), seharusnya SE yang bertajuk Petunjuk Teknis (Juknis) ini benar-benar berkualifikasi teknis, operasional, detail dan implementatif. Diantaranya adalah surat keterangan sehat jasmani dan rohani sebagaimana tercantum dalam Lampiran I Huruf B angka 2 huruf b angka 7). Seharusnya ketentuan yang tercantum jauh lebih teknis, operasional, detail dan implementatif sehingga mencegah munculnya kesimpangsiuran, ketidakjelasan, multiinterpretasi, kerancuan dan kontradiktif.

SE Nomor 315/KPU/V/2013 terbit sebagai respon KPU terhadap berbagai permasalahan yang muncul selama pelaksanaan verifikasi administrasi terhadap pemenuhan syarat pengajuan bakal calon dan pemenuhan syarat bakal calon. Namun, hal ini masih belum menjangkau seluruh permasalahan yang muncul dalam verifikasi oleh penyelenggara pileg di daerah, yaitu KPU Provinsi dan KPU Kabupaten/Kota.

\section{E. PENUTUP}

Berdasarkan analisis hasil penelitian, dapat disimpulkan bahwa produk kebijakan kepemiluan yang meliputi UU Nomor 8 Tahun 2012, PKPU Nomor 07 Tahun 2013, PKPU Nomor 13 Tahun 2013, SE Nomor 225/KPU/IV/2013 dan SE Nomor 315/KPU/V/2013 menunjukkan adanya hirarki dalam tatanan kebijakan publik secara keseluruhan. Konteks semua kebijakan tersebut adalah dinamika lingkungan kebijakan yang menghendaki penyempurnaan substansi kebijakan untuk pileg yang lebih berkualitas. Dalam pengaturan pencalonan anggota DPRD, yang termuat dalam UU Nomor 8 Tahun 2012 dan beberapa produk kebijakan KPU terdapat beberapa substansi kebijakan yang tidak jelas, multiinterpretatif, kontradiktif atau tidak konsisten, serta tidak operasional/tidak implementatif. Kondisi ini mengakibatkan penyelenggara pileg di daerah tidak dapat melaksanakan tugas pelayanan pencalonan secara lebih optimal. 
Berkenaan dengan itu, direkomendasikan perlu penyempurnaan substansi pengaturan pencalonan anggota DPRD, yang meliputi ijazah/STTB, surat keterangan sehat jasmani dan rohani, institusi pemberi surat keterangan sehat, petugas penghubung parpol, surat keterangan atau surat keputusan pemberhentian dalam kedudukan/jabatan tertentu (PNS, TNI, Polri, dan sebagainya), surat pernyataan pengunduran diri, badan lain yang anggarannya dari keuangan negara, pekerjaan lain yang tidak menimbulkan konflik kepentingan, beberapa contoh formulir/model pancalonan serta beberapa kesalahan/inkonsistensi peristilahan.

\section{DAFTAR PUSTAKA}

Anderson, James E. (1978). Public Policy-Making. Second Edition. New York : Holt, Rinehart and Winston.

Ball, Alan R. (1975). Modern Politics and Government. The Macmillan Press, Ltd.

Blondel, J. (2006). Comparative Government. An Introduction. Second Edition. London Prentice Hall/Harvester Wheatscheap.

Bromley, Daniel W, (1989). Economic Interest and Institution. The Conceptual Foundation of Public Policy. New York : Basil Blackwell Inc.

Budiardjo, Miriam. (1999). Demokrasi di Indonesia. Demokrasi Parlementer dan Demokrasi Pancasila. Jakarta: PT Gramedia Pustaka Utama.

Budiardjo, Miriam. (2008). Dasar-dasar Ilmu Politik. Edisi Revisi. Jakarta : PT Gramedia Pustaka Utama.

Dahl, Robert A. (1994). Dilema Demokrasi Pluralis. Antara Otonomi dan Kontrol (Terjemahan). Jakarta : CV Rajawali.

Dunn, William N. (1981). Public Policy Analysis : An Introduction. Prentice Hall Inc.Englewood Cliffts.

Dye, Thomas R. (1987). Understanding Public Policy. Sixth Edition. New Jersey : Prentice Hall Inc

Edwards III, George E. (1982). .Implementing Public Policy. Washington DC : Congressional Quarterly Press

Gerston, Larry N. (2010). Public Policy Making. Process and Principles. Third Edition. New York : .E.Sharpe

Howlett, Michael dan M. Ramesh. (1995). Studying Public Policy: Policy Cycles and Policy Subsystems. Toronto : Oxford University Press

Howlett, Michael. 2011. Designing Public Policies. Principles and Instruments. London : Routledge Taylor \& Francis Group

Jones, Charles O. (1984). Introduction to The Study of Public Policy. Third Edition. California :Brooks/Cole Publishing Company.

Krippendorff. Klaus. (1993). Analisis Isi. Pengantar Teori dan Metodologi. (Penerjemah : Farid Wajidi). Jakarta : PT RajaGrafindo Persada.

MacRae Jr. D. dan Wilde James. (1989). Policy Analysis for Public Decisions. New York : University Press of America. 
Mariana, Dede dan Caroline Paskarina. (2008). Demokrasi \& Politik Desentralisasi. Yogyakarta: Graha Ilmu

Marzuki, Peter Mahmud. (2015). Penelitian Hukum. Edisi Revisi. Jakarta : Prenadamedia Group. Michael, Ewen J. 2006. Public Policy. The Competitive Framework. Victoria : Oxford University Press

Miles, B. dan Huberman A.M. (1992). Analisis Data Kualitatif. Jakarta : UI Press.

Nazir, Moh. (2011). Metode Penelitian. Bogor : Ghalia Indonesia

Nasution, S. (1996). Metode Penelitian Naturalistik-Kualitatif. Bandung : Tarsito.

Post, James E dkk. (1999). Business and Society. Corporate Strategy, Public Policy, Ethics. Boston, Irwin McGraw-Hill.

Rakhmat, Jalaludin.(1999). Metode Penelitian Komunikasi. Bandung : PT Remaja Rosdakarya.

Soekanto, Soerjono dan Sri Mamudji. (2015). Penelitian Hukum Normatif. Suatu Tinjauan Singkat. Jakarta : PT RajaGrafindo Persada.

Surbakti, Ramlan. (1999). Memahami Ilmu Politik. Jakarta : Gramedia Widiasarana Indonesia

Wibawa, Samodra. (1994). Evaluasi Kebijakan Publik. Jakarta : PT RajaGrafindo Persada.

UU Nomor 8 Tahun 1974 tentang Pokok-pokok Kepegawaian

UU Nomor 3 Tahun 1999 tentang Pemilihan Umum.

UU Nomor 28 Tahun 1999 tentang Penyelenggara Negara Yang Bersih dan Bebas Dari Korupsi, Kolusi dan Nepotisme.

UU Nomor 43 Tahun 1999 tentang Perubahan Atas UU Nomor 8 Tahun 1974 tentang Pokokpokok Kepegawaian

UU Nomor 12 Tahun 2003 tentang Pemilihan Umum Anggota DPR, DPD dan DPRD.

UU Nomor 22 Tahun 2007 tentang Penyelenggara Pemilu.

UU Nomor 10 Tahun 2008 tentang Pemilihan Umum Anggota DPR, DPD dan DPRD.

UU Nomor 15 Tahun 2011 tentang Penyelenggara Pemilihan Umum.

UU Nomor 8 Tahun 2012 tentang Pemilihan Umum Anggota DPR, DPD dan DPRD.

UU Nomor 5 Tahun 2014 tentang Aparatur Sipil Negara

PKPU Nomor 07 Tahun 2013 tentang Pencalonan Anggota DPR, DPD dan DPRD Dalam Pemilu 2014.

PKPU Nomor 13 Tahun 2013 tentang Perubahan Atas PKPU Nomor 07 Tahun 2013 tentang Pencalonan Anggota DPR, DPD dan DPRD Dalam Pemilu Tahun 2014.

PKPU Nomor 07 Tahun 2012 tentang Tahapan, Jadwal dan Program Penyelenggaraan Pemilu Anggota DPR, DPD dan DPRD Tahun 2014.

PKPU Nomor 11 Tahun 2012 tentang Perubahan Atas PKPU Nomor 07 Tahun 2012 tentang Tahapan, Jadwal dan Program Penyelenggaraan Pemilu Anggota DPR, DPD dan DPRD Tahun 2014. 
SE KPU Nomor 225/KPU/IV/2013 tentang Juknis Tata Cara Pencalonan Anggota DPR, DPD dan DPRD

SE KPU Nomor 315/KPU/V/2013 tentang Temuan Hasil Verifikasi Administrasi Pemenuhan Syarat Pengajuan Bakal Calon dan Syarat Bakal Calon Anggota DPRD. 